EESTI NSV TEADUSTE AKADEEMIA TOIMETISED. VII KÖIDË BIOLOOGILINE SEERIA. 1958, NR. 3

ИЗВЕСТИЯ АКАДЕМИИ НАУК ЭСТОНСКОН ССР. ТОМ VII СЕРИЯ БИОЛОГИЧЕСКАЯ. 1958, 수 3

\title{
НАКОПЛЕНИЕ УРОЖАЯ СУХОГО ВЕЩЕСТВА И ИСПОЛЬЗОВАНИЕ ПЛАСТИЧЕСКИХ ВЕЩЕСТВ РАЗНЫМИ СОРТАМИ КРАСНОГО КЛЕВЕРА В ГОД ПОСЕВА
}

\author{
В. И. ДУШЕЧКИН, \\ кандидат сельскохозяйственных наук
}

В одном из беспокровных посевов сортоиспытания клевера в Хибинах на основании данных об урожаях сухого сена и соотношения веса укосной и стерневой частей и утолщенных корней $15-20$-ти сухих растений, взятых для гербария, был ориентировочно определен урожай воздушносухой массы надземных органов' и утолщенных корней, накопленный разными сортами клевера к середине (22/VII) и к концу лета (23/VIII) в год посева.

В посеве имелись резко различающиеся по биологическим и хозяйственным свойствам сорта: двуукосный украинский Веселоподолянский 331, не зимующий на севере, и одноукосные - Ярославский, слабозимостойкий в Хибинах, Хибины I - удовлетворительно зимующий, и Печорский дикорастущий, проявляющий очень хорошую зимостойкость на Крайнем Севере. Полученные данные (табл. 1) показали, что при значительных различиях в урожае укосной части в конце лета (менее зимостойкие дали более высокий урожай) сорта мало различались по сумме урожаев сухого вещества укосной части (стебли с листьями и цветочными головками и прикорневые листья), стерни (укороченные побеги, нижние части срезанных стеблей и черешков прикорневых листьев) и утолщенных корней. Вместе с тем полученные данные показали, что по высоте растений и по соотношению урожая надземных органов и утолщенных корней в середине лета сорта отличались значительно меньше, чем в конце.

Для получения более точных данных, характеризующих накопление общего урожая разными сортами клевера, в Хибинах были поставлены специальные опыты.

25 июня 1948 г. три сорта - Белоцерковский 3306 (южный двуукосный, не зимующий в Хибинах), Хибины I и Печорский - были посеяны в ящики площадью 0,5 кв. м, по 1 г всхожих семян каждого сорта на один ящик. Ящики, были наполнены перегнойной землей в смеси с песком и минеральными удобрениями, внесенными из расчета по 6 г $\mathrm{P}_{2} \mathrm{O}_{5}, \mathrm{~K}_{2} \mathrm{O}$ и $\mathrm{N}$ на 1 кв. м.

Через месяц листья растений почти закрыли поверхность почвы. 29 июня, когда растения началіи перерастать стенки ящиков, на края последних были поставлены рамы из досок высотой в 13 см, с тем чтобы лишить растения бокового освещения и устранить преимущество, кото- 


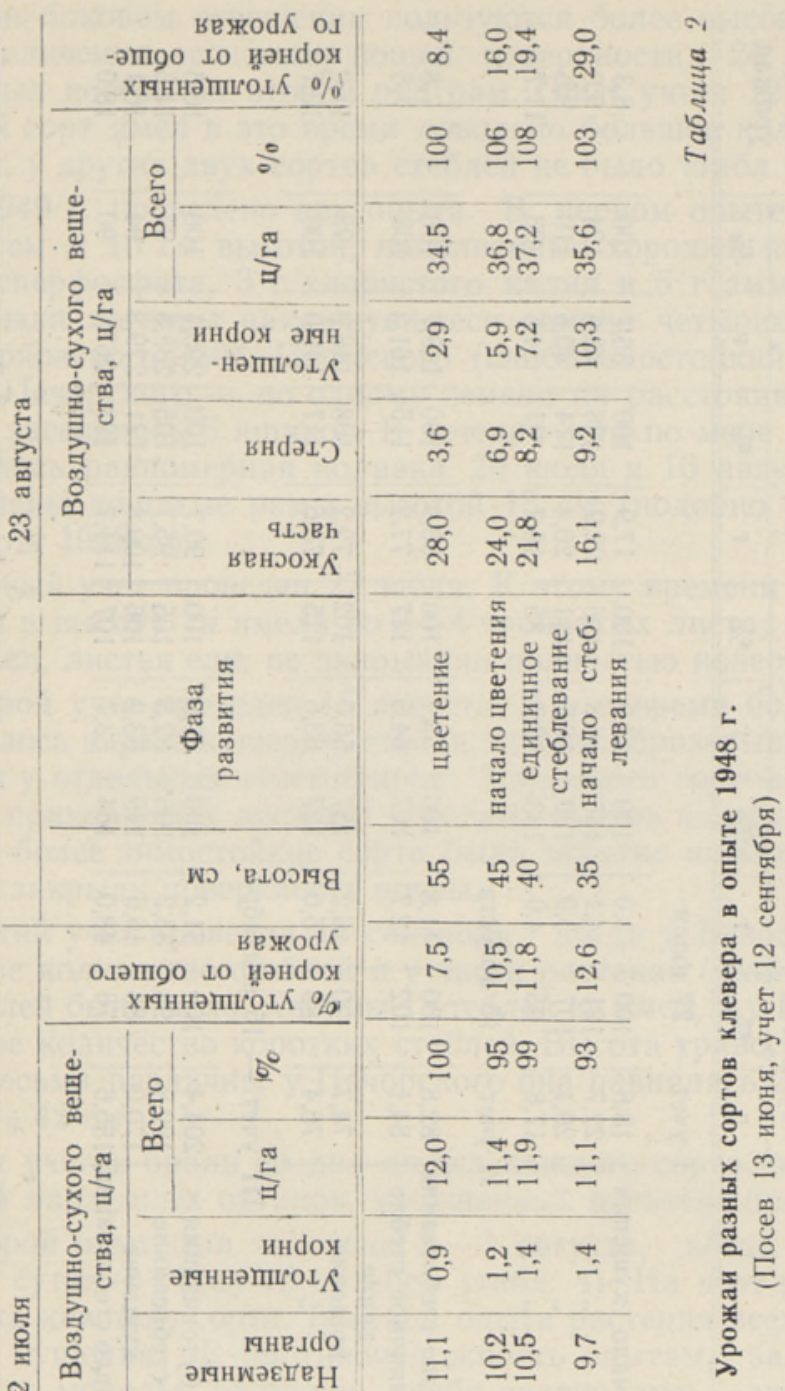

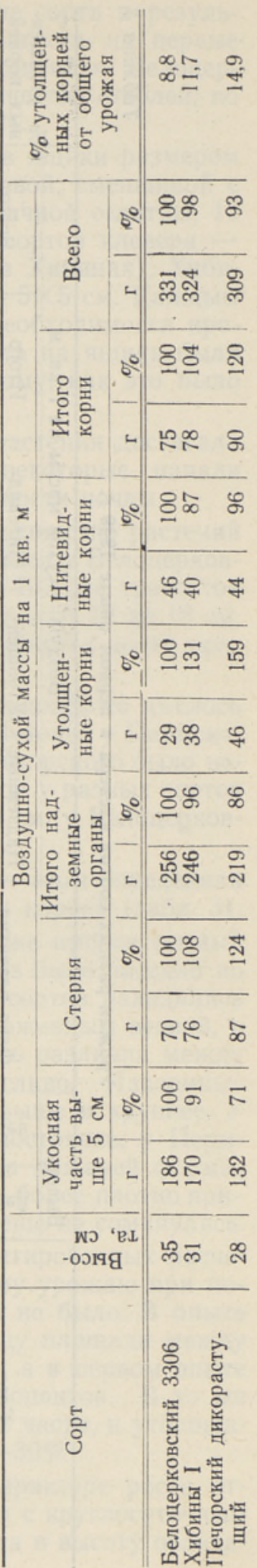




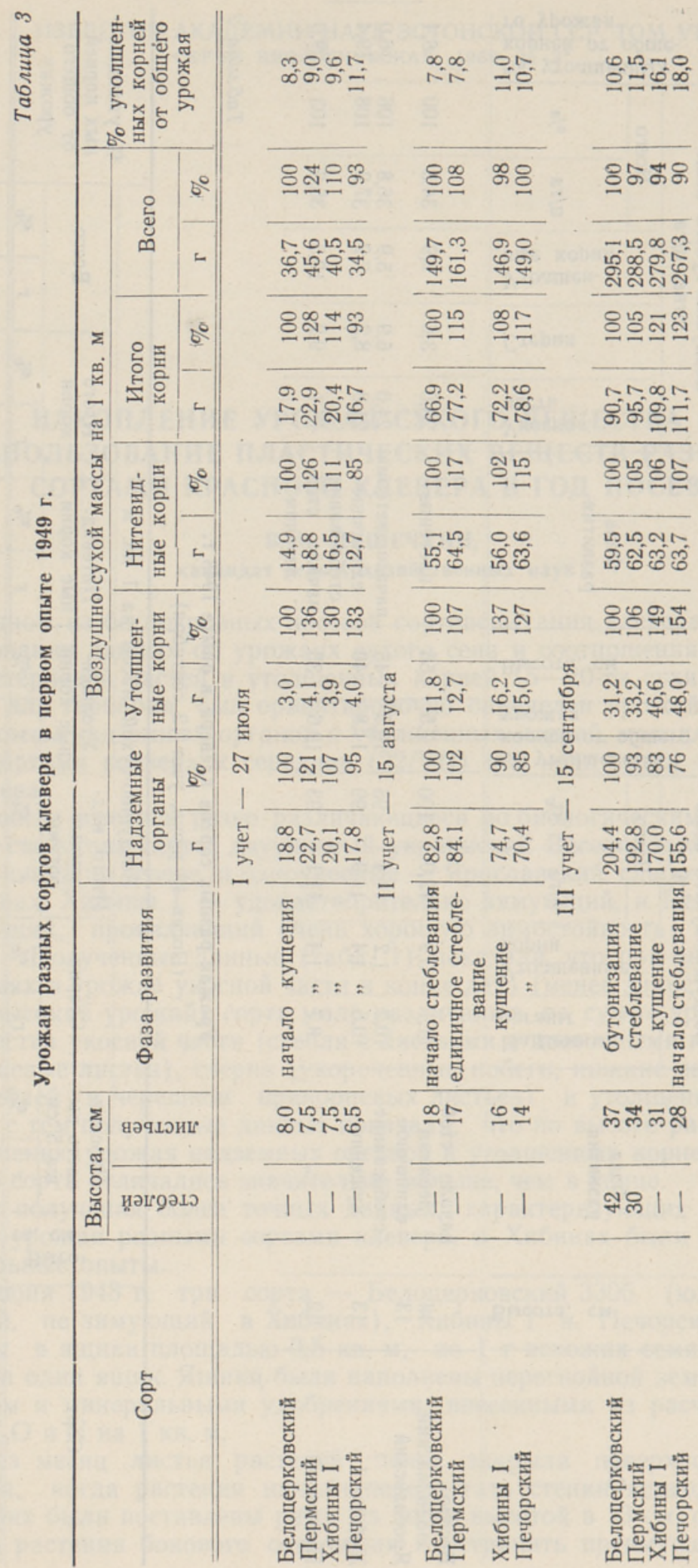


рым при боковом освещении пользуются более высокие сорта в результате увеличения ассимилирующей поверхности. 25 августа на первые рамы был поставлен второй ряд рам. Опыт учтен 12 сентября. Белоцерковский сорт имел в это время довольно большое количество стеблей, но не цвел, у других двух сортов стеблей не было (табл. 2).

В 1949 г. проведено два опыта. В первом опыте в ящики размером $50 \times 50$ см и 15 см высотой, наполненные хорошей почв'ой, смешанной с 7,5 г суперфосфата, 3 г хлористого калия и 5 г аммиачной селитры, 13 июня были посеяны наклюнувшиеся семена четырех сортов клевера Белоцерковского 3306, Пермского (слабозимостойкий в Хибинах), Хибины I и Печорского - по одному семени на расстоянии $5 \times 5$ см. Каждым сортом засевалось 6 ящиков. В течение лета по мере необходимости производилась равномерная поливка. 20 июля и 10 августа на ящики были поставлены дощатые рамы высотой 15 см (подобно тому, как это было сделано в 1948 г.).

Первый учет проведен 27 июля. К этому времени растения достигали $6-8$ см в высоту и имели по 3-4 тройчатых листа; некоторые начали куститься, лнстья еще не закрывали полностью поверхности почвы.

Второй учет проведен 15 ав'уста. В это время большинство растений находилось в фазе кущения, стебли начали образовываться у Белоцерковского и у отдельных экземпляров Пермского сортов. Высота травостоя (яруса прикорневых листьев) у разных сортов колебалась от 13 до 18 см, причем более зимостойкие сорта были заметно ниже. Листья почти полностью закрыли поверхность почвы.

Третий учет проведен 15 сентября, когда у Белоцерковского имелось большое количество стеблей и у части растений были бутоны, у Пермского стеблей было мало, Хибины I стеблей не имел, а у Печорского было небольшое количество коротких стеблей. Высота травостоя у разных сортов была весьма различна: у Печорского она равнялась 28 см, у Белоцерковского - 42 см.

Для учетов брали по два ящика каждого сорта, при этом определяли урожай надземных органов, утолщенных и нитевидных корней (табл. 3).

Второй опыт был заложен $1-3$ августа, когда уже имелся темный период суток, и учтен 10 октября (табл. 4). На этот раз было посеяно по 2 ящика каждого сорта. В конце опыта растения всех сортов находились в фазе кущения. В противоположность опытам, заложенным весной, в которых молодые растения слабо различались, здесь различия между сортами с самого начала опыта были выражены отчетливо. Надземные органы менее зимостойких сортов были значительно выше и крупнее. У Белоцерковского кустики были до конца опыта прямостоячие, у Пермского - слабо развалистые, у Хибины I была розетка лежачей формы, у Печорского также лежачей, но черешки листьев были более плотно прижаты к земле. Ко дню учета листья ни у одного сорта еще не сомкнулись.

Проведенные опыты подтвердили результаты ориентировочных расчетов, проведенных в посевах сортоиспытания: по общему урожаю при посевах в начале лета между сортами больших отличий не было. В опыте 1948 г. (табл. 2) различия в' общем урожае на единицу площади между разными сортами осенью не превышали 7 процентов, а в первом опыте 1949 г. (табл. 3) при последнем сроке учета -10 процентов. В то же время урожай надземных органов, особенно их укосной части, и утолщенных корней различался значительно сильнее - до $25-30 \%$.

Можно отметить следующую закономерность в характере роста отдельных сортов. Пока в Хибинах продолжается период с круглосуточным днем, разные по зимостойкости сорта по скорости роста в высоту отлича-

2 ENSV TA Toimetised B-3 58 
ются значительно меньше, чем в' период, когда день уже идет на убыль. ذолее зимостойкие сорта при сокращении дня начинают расти в высоту медленнее, чем менее зимостойкие. Однако, что очень важно, общего более сильного замедления процессов жизнедеятельности зимостойких сортов в это время не происходит. Одновременно с замедлением роста надземных органов в' высоту усиливается рост главного корня и боковых его утолщенных ответвлений, а также увеличивается вес оснований укороченных зимующих побегов (главным образом за счет их утолщения). В связи с этим по соотношению урожая надземных органов и корней в Іериод круглосуточного дня отличия между сортами значительно меныше. чем осенью при более коротком дне.

Таблица 4

Урожаи разных сортов клевера во втором опыте 1949 г.

(Посев 1-3 августа, учет -10 октября)

\begin{tabular}{|c|c|c|c|c|c|c|c|c|c|}
\hline \multirow{3}{*}{ Copt } & \multirow{3}{*}{ 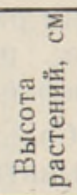 } & \multirow{3}{*}{ 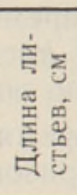 } & \multicolumn{6}{|c|}{ Воздушно-сухой массы на 1 кв. м } & \multirow{3}{*}{$\begin{array}{c}\% \text { корней } \\
\text { от общего } \\
\text { урожая }\end{array}$} \\
\hline & & & \multicolumn{2}{|c|}{$\begin{array}{c}\text { Надземные } \\
\text { органы }\end{array}$} & \multicolumn{2}{|c|}{ Корни } & \multicolumn{2}{|c|}{ Bcero } & \\
\hline & & & $r$ & $\%$ & $r$ & $\%$ & $\Gamma$ & $\%$ & \\
\hline $\begin{array}{l}\text { Белоцерковский } \\
\text { Пермский } \\
\text { Хибины I } \\
\text { Печорский }\end{array}$ & $\begin{array}{l}7,0 \\
6 \\
3 \\
2,5\end{array}$ & $\begin{array}{l}8 \\
7 \\
5 \\
4,5\end{array}$ & $\begin{array}{l}17,0 \\
11,2 \\
11,0 \\
10,8\end{array}$ & $\begin{array}{r}100 \\
66 \\
65 \\
64\end{array}$ & $\begin{array}{l}4,4 \\
5,0 \\
7,0 \\
7,0\end{array}$ & $\begin{array}{l}100 \\
113 \\
160 \\
160\end{array}$ & $\begin{array}{l}21,4 \\
16,2 \\
18,0 \\
17,8\end{array}$ & $\begin{array}{r}100 \\
65 \\
84 \\
83\end{array}$ & $\begin{array}{l}20,6 \\
30,8 \\
38,9 \\
39,4\end{array}$ \\
\hline
\end{tabular}

В литературе по фотосинтезу уже отмечалось, что у разных по урожайности сортов одного вида растений или даже у разных видов интенсивность фотосинтеза бывает очень сходной $\left[{ }^{5}, 7,8,97\right.$. У разных сортов' одного вида и даже у разных видов отмечалось также сходство в интенсивности накопления сухого вещества на единицу площади в сомкнутых траво- и древостоях.

Указанное явление, по мнению некоторых исследователей, проявляется в оптимальных условиях роста, когда различия в биологических свойствах видов и сортов' не сказываются на обеспечении листового аппарата материалом для фотосинтеза и интенсивность его определяется в основном температурными условиями и весьма выравненной в природных условиях концентрацией $\mathrm{CO}_{2}$.

Следует при этом заметить, что сходство в интенсивности фотосинтеза у ғазных сортов или видов определяется, очевидно, не столько наличием оптимальных условий для жизнедеятельности растений, сколько равномерностью поступления в растения разных сортов влаги и элементов минерального питания, что чаще имеет место при благоприятных условиях почвенного питания.

В опытах, описанных выше, растения всех сортов клевера были хорошо обеспечены как влагой, так и элементами минерального питания. Различия же в высоте растений разных сортов при посевах в начале лета не сказывались на интенсивности накопления урожая на единицу площади в связи с тем, что в первую половину лета при круглосуточном дне все сорта росли и развивали листовую поверхность почти одинаково быстро. Во второй же половине лета, когда день становился короче, листья соседних растений уже смыкались и дальнейший прирост в высоту, очевидно, уже мало влиял на количество поглощаемого травостоем света. В связи с этим возникшие к осени различия в высоте не оказывали большого влияния на интенсивность ассимиляции $\mathrm{CO}_{2}$ на единицу площади посева у разных сортов'. 
Некоторые различия в общем урожае, имевшие место в опыте 1948 г. и в первом опыте 1949 г. при последнем учете, где урожай высокорослых сортов был немного выше урожая низкорослых, можно объяснить тем, что травостой в этих опытах не достиг той высоты (а, может быть, и густоты), при которой количество поглощаемого разными сортами света полностью выравнивается.

Если же клевера высевались во второй половине лета, как это имело место во втором опыте 1949 г. (табл. 4), то различия в росте и в площади листьев между сортами проявлялись уже очень скоро. У менее зимостойких надземные органы росли быстрее, и они скорее развивали большую поверхность листьев. В этом случае уже до смыкания листьев возникали существенные отличия в общем урожае.

Подобное быстрое проявление различий в урожае уже у молодых растений имеет место в более южных районах при посевах в' любые сроки летом, причем при более длинном дне оно выражено менее резко, а при коротком более отчетливо. После же смыкания листьев и достижения травостоем достаточной высоты и густоты прирост сухого вещества на единицу площади у разных сортов', очевидно, нередко выравнивается.

Чтобы проверить, имеют ли разные по биологическим свойствам сорта клевера сходную чистую продуктивность фотосинтеза на единицу площади листьев, в 1957 г. в Таллине были проведены два соответствующих опыта. В первом опыте, заложенном 15 июля, по 10 молодых 46-дневных растений местного двуукосного сорта Иыгева 433 и сорта Хибины I были посажены по одному растению в вегетационные сосуды, наполненные хорошей почвой, удобренной $1,7 \Gamma \mathrm{Ca}_{3}\left(\mathrm{PO}_{4}\right)_{2}$ и $1,1 \Gamma \mathrm{KCl}$ на сосуд. Влажность почвы поддерживалась на уровне $50 \%$ от полной влагоемкости. В день посадки был определен сухой вес десяти таких же растений каждого сорта, который был принят за исходный сухой вес посаженных растений.

После посадки, а затем через каждые $7-8$ дней у подопытных растений измерялись длина и ширина развернувшихся дисточков. 13 августа растения были извлечены из сосудов, высушены в термостате и взвешены.

В день учета опыта у пяти растений Иыгева 433 имелись начинавшие цвести стебли длиной до 30 см, остальные растения стеблей не имели. Кустики этого сорта были слабо развалистой формы. Растения Хибины I находились в фазе кущения, розетка листьев была лежачей и полулежачей.

Опасаясь, что клубеньковые бактерии могут по-разному развиться на корнях столь различных по биологии сортов, вследствие чего могло бы возникнуть различие в обеспечении их азотом, что, в свою очередь, могло повлиять на фотосинтез, мы заложили 30 июля второй аналогичный опыт, но с внесением в почву, кроме фосфора и калия, также минерального азота в количестве 2 г $\left(\mathrm{NH}_{4}\right)_{2} \mathrm{SO}_{4}$ на сосуд. Для этого опыта были взяты 32 -дневные растения сортов Йгева 433 и Ярослав'кого, высотой около 5 см, имевшие по два развернутых тройчатых листа. Опыт продолжался до 23 сентября.

В отличие от первого, в этом опыте растения сорта Йыгева 433 стеблей не образовали (лишь у одного растения из десяти был один короткий стебель), высота их к концу опыта доходила до 12 см и они имели в среднем по 5,8 побегов. Ярославский стеблей не образовал, высота его также составляла около 12 см, побегов было в среднем 6,3 шт. Форма кустиков y Йгева 433 в этом опыте резко отличалась от формы их в опыте, заложенном 15 июля: у всех растений этого сорта, так же как у Ярославского, сформировалась лежачая и полулежачая розетка листьев'.

По размерам листочков, имеющих у молодых растений эллипсовидную 
форму, была вычислена их площадь. При помощи кривой нарастания площади листьев, нанесенной на миллиметровую бумагу, была установлена средняя площадь листьев в период каждого опыта. По приросту сухого в'щества и средней площади листьев определили прирост на единицу площади листьев, а затем чистую продуктивность фотосинтеза на 1 кв. дцм листьев в сутки (табл. 5).

Как в первом, так и во втором опытах чистая продуктивность у разных сортов оказалась очень сходной. В первом опыте она составила в среднем за весь период опыта у сорта Йгева 433 - 49 мг, а у Хибины I - 43 мг в сутки на 1 кв. дцм площади листьев. Во втором опыте чистая продуктивность фотосинтеза была равна у Йгева 433 - 16 мг, у Ярослав'ского - $18 \mathrm{mr}$.

Қлубеньковые бактерии хорошо развились у растений всех сортов' в обоих опытах, а внесение минерального азота во втором опыте, очевидно, существенного значения для улучшения азотного питания не имело.

Полученные цифры характеризуют интенсивность накопления урожая главным образом в последний период каждого из опытов, когда образовалось больше листьев.

Большое различие в интенсивности накопления сухого вещества объясняется значительными различиями в' длине дня и в температурах во второй половине опытов. В период проведения первого опыта длина дня составляла $18-16,5$ часов, во время в'орого опыта она уменьшилась и равнялась 17-12 часам. В первом опыте средняя площадь листьев приходилась на 4-6 авгуета, когда среднесуточная температура равнялась $17-18^{\circ}$, а во втором опыте на $15-16$ сентября, когда температура была $11-12^{\circ}$.

Из данных о структуре урожая, представленных в' табл. 5, видно, что сорта, накопляя пластические вещества с одинаковой интенсивностью на единицу площади листьев, использовали эти вещества различно. В первом опыте, например, у сорта Иыгева 433 значительную часть урожая составляли стебли, которых у Хибины I почти не было. Процент же утолщенных корней у Хибины I был в' полтора раза выше, чем у Иыгева 433. Больше весили у Хибины I также и оси укороченных побегов. Следовательно, сорт Хибины I в большей степени использовал пластические вещества на увеличение размеров зимующих органов - укороченных побегов' и утолщенных корней, в которых, как известно, отлагаются запасы на зиму. Во втором опыте, при более коротком дне, Йгева 433 уже более интенсивно формировал зимующие органы и по структуре урожая между этим сортом и одноукосным Ярославским резких отличий не было, но все же у Ярославского утолщенные корни были крупнее и составляли по весу больший процент урожая, а оси укороченных побегов у Иыгева 433 были несколько сильнее вытянуты и весили как абсолютно, так и в процентах от всего урожая больше, чем у Ярославского, у которого эти оси были короче и несколько толще.

Опыты, проведенные в' Хибинах и в Таллине, подтверждают по существу уже сделанный исследователями фотосинтеза, очень важный для селекционеров вывод: объяснение особенностей поведения сортов клевера (так же, как и многих других видов) и различной их урожайности следует искать не в различной их способности к фотоеинтетической деятельности в тех условиях, в которых мы их обычно выращиваем (она может различаться, но уже по вторичным причинам), а в «механизме», опреде- 


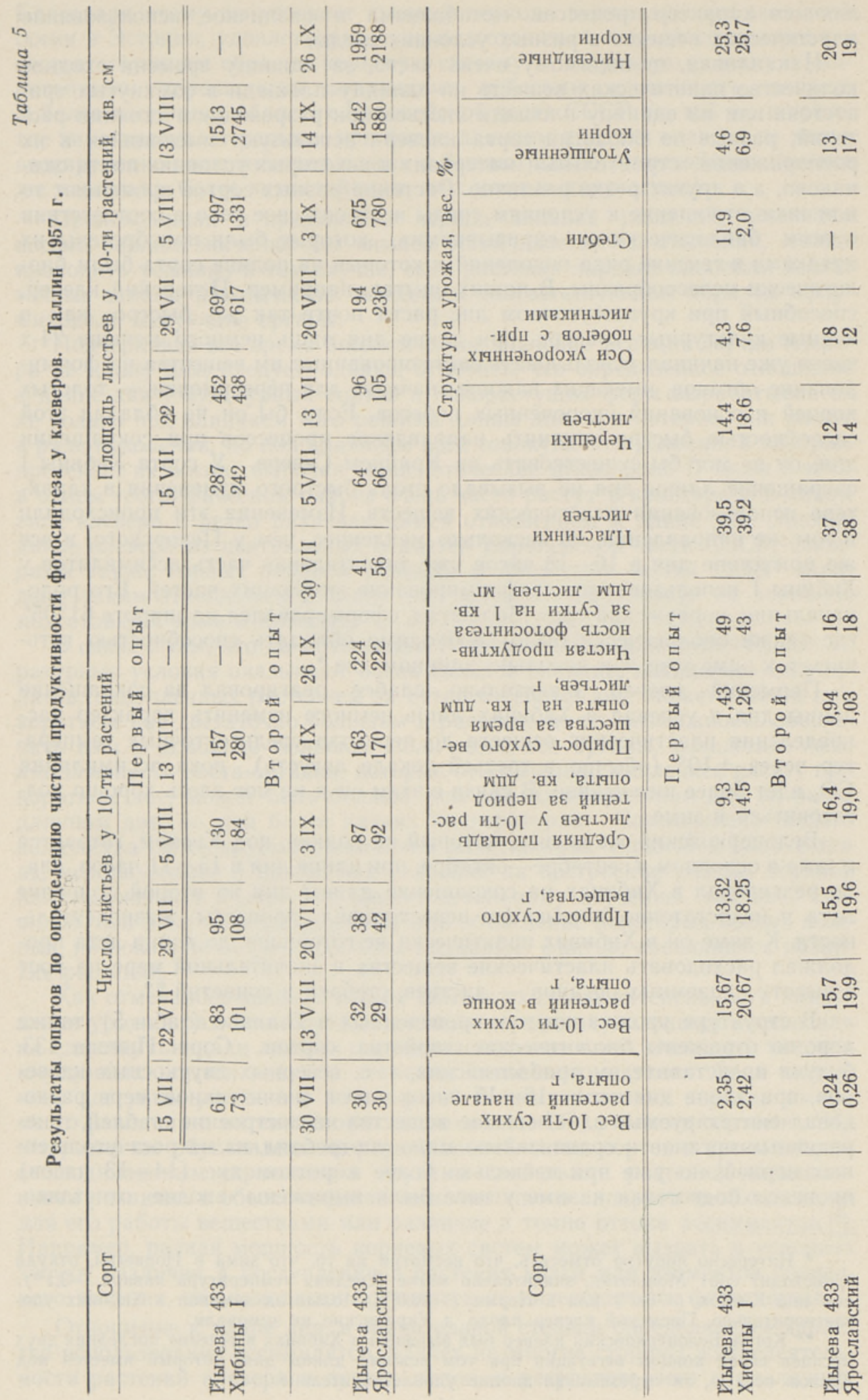


ляющем характер процессов метаболизма и различное использование пластических веществ в разных условиях среды.

Накапливая, по-видимому очень часто, за единицу времени сходное количество пластических веществ на единицу площади в сомкнутых травостоях или на единицу площади листьев при разреженном стоянии растений, разные по биологии сорта клевера используют имеющийся в их распоряжении «строительный материал» в некоторых условиях почти одинаково, а в других резко различно. Растения разных сортов проявляют то или иное отношение к условиям среды и строят свое тело в соответствии с теми биологическими «привычками», которые были приобретены их предками в течение ряда поколений и которые на родине сорта были биологически целесообразны. В наших опытах, например, Печорский клевер, способный при круглосуточном дне расти почти так же быстро, как и южные культурные клевера, при длине дня лишь немного меньше 24-х часов уже начинал использовать синтезированные им вещества на формирование органов, имеющих важное значение для перезимовки - толстых корней и оснований укороченных побегов. Если бы он не обладал этой способностью быстро изменять направление процессов' при сокращении дня, он не мог бы существовать на Крайнем Севере. У сорта Хибины I сокращение длины дня не вызывало столь быстрого изменения в характере использования пластических веществ. Изменения эти происходили в' том же направлении, но несколько медленнее, чем у Печорского, и все же при длине дня в 16-18 часов уже значительная часть ассимилятов у Хибины I использовалась на формирование зимующих частей. Его родоначальник, норвежский сорт Мольштад, сформировался на широте $61^{\circ} 05^{\prime}$, где также биологически было необходимо обладать способностью готовиться к зиме уже при довольно длинном дне *.

Пермский клевер значительно слабее реагировал на сокращение длины дня и успевал в Хибинах лишь немного изменить характер распределения пластических веществ до перехода среднесуточных температур через $+10^{\circ}$ (обычно в третьей декаде августа), пока ассимиляция $\mathrm{CO}_{2}$ идет более интенсивно. В связи с этим он и не мог здесь хорошо подготовиться к зиме.

Белоцерков'ский же клевер, который на родине, под Киевом, готовится к зиме в основном в' сентябре-октябре, при длине дня в $13-11$ часов, слабо реагировал в Хибинах на сокращение длины дня во второй половине лета и недостаточно интенсивно перестраивал процессы жизнедеятельности. К зиме он в Хибинах практически не готовился, до конца лета продолжал расходовать пластические вещества в значительной мере на рост в высоту надземных органов - листьев, стеблей и соцветий **.

В структуре урожая опытов, проведенных в Таллине (табл. 5), также хорошо отражены биологические свойства сортов. Сорт Иыгев'а 433. будучи представителем прибалтийских, т. е. северных двуукосных клеверов, при длине дня около $16-15$ часов еще в значительной мере расходовал синтезируемые пластические вещества на построение стеблей, генеративных органов и сравнительно мало употреблял их на рост утолщенных корней, но уже при несколько более коротком дне (14-13 часов) процессы подготовки к зиме у него были выражены вполне отчетливо.

* Интересно попутно отметить, что несмотря на то, что зима в Норвегии, откуда происходит сорт Мольштад, значительно мягче (средняя температура января $-3,1^{\circ}$ ), чем под Кневом $\left(-6,0^{\circ}\right)$ или в Перми $\left(-16,0^{\circ}\right)$, Мольштад зимовал в Хибинах удовлетворительно, Пермский клевер плохо, а Украинские не зимовали.

** Когда Белоцерковский клевер был выращен в Хибинах в течение последних двух месяцев перед концом вегетации при том режиме длины дня, который нмеется под Кневом осенью, он перезимовал вполне удовлетворительно. 
Благодаря этому он успевает к концу периода вегетации, при затяжной осени в' Эстонии, удовлетворительно подготовиться к зиме: сформировать соответствующим образом корневую систему и зимующую розетку с укороченными коренастыми зимующими побегами и накопить запасы. В более восточных областях Европейской части СССР, на той же широте, где зима наступает раньше, при более длинном дне, эти клевера не могут своевременно подготовиться к зиме и бывают слабо зимостойкими (но в'се же несколько более зимостойкими, чем южные двуукосные).

Происходящая в предзимний период закалка растений, имеющая весьма важное значение для зимней устойчивости, без сомнения, может проходить успешно в том случае, если растения заранее накопили достаточные запасы пластических веществ и соответствующим образом сформировали зимующие органы.

Подчеркивая все время биологическое значение реакции сортов' клевера на длину дня, следует, однако, отметить, что определенное отношение к длине дня у культурных сортов и дикорастущих форм вырабатывается не только под влиянием того режима длины дня, при котором они живут в ряде поколений, но под влиянием всей совокупности условий, в которых протекает их жизнь, включая биоценотические отношения. В связи с этим в одном географическом районе очень часто растут в' культуре и в диком виде клевера с резко различающимся отношением к длине дня. Многие дикие клевера из центральных областей Европейской части СССР, Сибири, а также горных районов Кавказа и Азиатских частей СССР обладают таким отношением к длине дня, которое обеспечивает им хорошую подготовку к зиме в Хибинах.

В св'язи с тем, что на интенсивность фотосинтеза, как известно, температурные условия оказывают очень сильное влияние, количество ассимилятов, накопленных растением за сутки в теплые дни, может быть и при коротком дне достаточно большим и растение имеет возможность обеспечить ими в довольно большом количестве в'е органы; вследствие чего интенсивность роста органов, которые относительно медленнее растут при коротком дне, может быть больше, чем при благоприятном для их роста длинном дне, но при более низких температурах. Соотношение общего количества синтезируемых растением пластических веществ и количества их, используемого в различных условиях на построение разных органов или отложенных в запас, подлежит детальному изучению, так как, очевидно, при этом можно будет получить объяснение некоторых весьма важных, но пока еще не разъясненных правильно фактов, касающихся развития растений.

Как отмечалось выше, в наших опытах сходство интенсивности накопления урожая разными сортами клевера на единицу площади посева или на единицу площади листьев определялось в основном, очевидно, тем, что в условиях опытов влага и элементы почвенного питания были одинаково доступны растениям всех сортов. В иных условиях нередко имеют место различия в интенсивности ассимиляции $\mathrm{CO}_{2}$ разными сортами. Но эти различия обусловлены не разной способностью сортов к ассимиляции, а неодинаковым строением и другими свойствами растений, вызывающими различие в обеспечении ассимиляционного аппарата необходимыми для его работы веществами или различие в темпе оттока ассимилятов $\left[{ }^{8}\right]$ Например, разная мощность корневых систем может вызвать в условиях засухи различия в' поступлении в растения влаги или элементов почвенного питания, что немедленно отразится на интенсивности фотосинтеза.

Отношение к длине дня, в значительной степени определяющее характер использования ассимилятов, влияет на многие стороны жизнедеятельности растений клевера и других видов, в результате чего в различных 
условиях могут складыв'аться весьма разные отношения растений и среды (среды в широком смысле слова), приводящие к разным биологическим последствиям и к разному хозяйственному эффекту. Эти стороны жизнедеятельности разных сортов должны быть изучены, чтобы можно было глубже уяснить свойства сортов, понять их биологическое значение и св'язь с хозяйственно важными свойствами.

В данной работе изучалось лишь накопление сухого вещества разными сортами и показана зависимость распределения пластических веществ от длины дня и биологических свойств сортов. Очень важно обратить в дальнейшем в'нимание и на изучение качества ассимилятов, образующихся у разных по биологии сортов, и процессов' их метаболизма в тех нли иных условиях. Это позволит глубже понять особенности отношения сортов к отдельным внешним факторам и их комплексам, установить сбщие закономерности онтогенеза и, очевидно, даст возможность вскрыть причины, определяющие изменение свойств сортов, в том числе таких важных св'ойств, как отношение к длине дня и связанная с ним зимостойкость.

\section{Выводы}

1. Разные сорта красного клевера при одинаковом обеспечении влагой и элементами минерального питания накапливают урожай сухого вещества в надземных органах и корнях на единицу площади посева в сомкнутых травостоях или на единицу площади листьев при одиночном стоянии растений с одинаковой или почти одинаковой интенсивностью.

2. При круглосуточном дне разные сорта клевера используют пластические вещества почти одинаково, преимущественно на рост надземных органов в высоту. Вследствие этого в'се они растут на круглосуточном дне относительно очень быстро, причем различий в скорости роста между сортами нет или же эти различия сравнительно незначительны.

3. При сокращении длины дня направление использования пластических веществ изменяется. Они в' меньшей мере расходуются на рост надземных органов в высоту, а в большей степени - на образование необходимых для перезимовки органов - утолщенных корней и укороченных побегов.

4. Характер реакции на изменение длины дня у разных сортов' клевера в основном сходен, но интенсивность ее проявления различна. Более зимостойкие сорта реагируют на сокращение длины дня более резко и быстрее перестраивают свои процессы в сторону подготовки к зиме, чем менее зимостойкие.

5. От соотношения количества пластических веществ', используемых сортами при разной длине дня на рост надземных органов, на развитие листовой поверхности, на рост и утолщение корней и других зимующих органов и на отложение запасов в них, зависит как урожай укосной части надземных органов', так и степень подготовки к зиме. Температурные условия при этом имеют существенное значение, поскольку от них в значительной мере зависит интенсивность ассимиляции и ростовых процессов. Значение температуры, конечно, не исчерпывается этим, однако в данной статье этот вопрос не рассматривается.

6. Проведенные опыты еще раз подтв'ерждают важнейшее биологическое значение зависимости интенсивности и характера физиологических процессов у растений от длины дня, на что уже неоднократно указывалось в литературе. Благодаря наличию у растений способности опреде- 
ленным образом реагировать на длину дня, они могут заблаговременно перестраивать процессы своей жизнедеятельности и приспосабливаться к сезонным изменениям внешних условий. В новых, необычных для сорта условиях иной режим длины дня может «обмануть» растения сорта и обусловить такой ход их роста и развития, которые приведут их к гибели.

7. В связи с тем, что в условиях культуры в интенсивности фотосинтеза отличий между разными сортами клевера, очевидно, часто не бывает или же эти отличия незначительны, основные причины, определяющие различия в поведении и в урожайности сортов, следует искать в процесcax, управляющих метаболизмом и использованием пластических веществ'.

Для освещения процессов формирования урожая сортами клевера в последующие годы жизни, являющихся более сложными, чем в год посева, требуются дополнительные исследования.

\title{
ЛИТЕРАТУРА
}

1. В а с и ль е в И. М., Зимовка растений. Изд. АН СССР, 1956.

2. Д уш е к и н В. И., В каком состоянии зимуют побеги многолетних трав. Докл. AH CCCP, т. 76,1951 , № 6.

3. Душеч ки н В. И., О скорости роста различных форм красного клевера при разной длине дня. Докл. АН СССР, т. 81, 1951, № 1 .

4. Д ушечкин В. И., О биологических причинах, определяющих зимостойкость многолетних злаковых трав. Докл. АН СССР, т. 85, 1952, № 1.

5. Ив анов Л. А., Фотосинтез и урожай. Сб. работ по физиол. раст. памяти К. А. Тимирязева. М., 1941.

6. Қ а т ун ски й В. М., О приспособительном значении фотопериодической реакции растений. Сб. научн. работ комсомольцев-биологов. М., 1939.

7. К а тун ск и й В. М., Интенсивность фотосинтеза как основной показатель углеродного питания растений. Сб. работ по физиол. раст. памяти К. А. Тимирязева. М., 1941.

8. Н и ч и п о р о в и ч А. А., Световое и углеродное питание растений. Изд. АН СССР, 1955.

9. О с т а п енко Л. А., Фотосинтез у карликовых и гигантских форм растений. Рефераты научно-исслед. работ за 1945 г. Отделение биол. наук АН СССР, 1947.

10. Т ум а н о И. И., О физиологических основах зимостойкости растений. Вестн. АН CCCP, 1955, №. 5 .
Институт экспериментальной биологии Академии наук Эстонской ССР
Поступила в редакцию
10 XII 1957

\section{KUIVAINESAAGI KOGUMINE JA PLASTILISTE AINETE KASUTAMINE PUNASE RISTIKU SORTIDE POOLT ESIMESEL ELUAASTAL}

\author{
V. Dušetškin, \\ põllumajandusteaduste kandidaat
}

Resümee

Eri geograafilistest rajoonidest pärinevad ja erinevates keskkonnatingimustes arenenud punase ristiku sordid annavad heades niiskus- ning toitumistingimustes ja taimede teatava minimaalse kōrguse juures kogusaaki (lehestik koos juurestikuga) voordselt või peaaegu vōrdselt kasvupinnaühiku (liitunud taimkatte puhul) vōi lehepinnaühiku kohta (taimede üksikuna asetsemise puhul).

Vōrdsetes kasvutingimustes kasvupinnaühiku või lehepinnaühiku kohta peaaegu võrdselt toodetavat orgaanilist (sünteesitud plastilist) ainet kasutavad ristikusordid, olenevalt nende bioloogilistest omadustest ja sellest, millistes keskkonnatingimustes need sordid kujunesid, oma kasvuprotsessis erinevalt.

Ristikusortide plastiliste ainete kasutamine sōltub peamiselt nende suhtumisest päeva 
pikkusesse. Hibiinidel korraldatud katsetega on tõestatud, et 24-tunnise päevapikkuse juures kasutavad eri sordid assimilaate vôrdlemisi ühesuguselt - peamiselt maapealsete osade kasvuks. Päeva pikkuse kahanedes aga hakkavad assimilaatide kasutamises ilmnema sortide vahel erinevused, mis väljenduvad seda teravamalt, mida lühemaks muutub päev.

Päeva pikkuse kahanemine ja sellest sōltuvad muudatused plastiliste ainete jaotumises mitmesuguste organite ülesehitamiseks kutsuvad kōigil ristikusortidel esile iseloomu poolest pōhiliselt sama, kuid intensiivsuselt erineva reaktsiooni.

Hibiinidel oli eriti selgesti näha, et kôik ristikusordid hakkasid pärast 24 tunni pikkuse päeva loppemist kasutama plastilisi aineid talvitamiseks vajalike organite moodustamiseks. Seejuures reageerisid talvekindlamad sordid päeva pikkuse kahanemisele teravamalt, korraldades oma kasvuprotsesse intensiivsemalt ümber. See väljendus eelkõige maapealsete osade kasvu seismajäämises, peajuure ning jämedamate külgjuurte kasvu hoogustumises ja lühikeste talvitusvõrsete kaalu suurenemises. Selle protsessi intensiivsus määras külviaasta suve lōpuks antud sordi talvitusastme ja ta pealsete niiteosa saagi. Oluline tähtsus seejuures on temperatuuril, millest suurel määral sōltub $\mathrm{CO}_{2}$ assimileerimise intensiivsus.

Füsioloogiliste protsesside intensiivsuse ja iseloomu olenevus päeva pikkusest, mis selgesti ilmnes meie katsetest, omab olulist bioloogilist tähtsust, mida on märgitud teisteski uurimustes. Olenevalt taimede eri suhtumisest päeva pikkusesse võivad nad nii või teisiti ümber korraldada oma elutegevuse (kasvu, arengu, varuainete talletamise jm.), kohanedes enam vôi vähem välistingimustega, eelkơige meteoroloogiliste tegurite perioodiliste muutustega.

Artiklis on näidatud, et ristikusortide suhtumine päeva pikkusesse kujuneb välja fülogeneesiprotsessis, olles bioloogiliselt otstarbekohane seal, kus sort formeerus. Kui sort satub uutesse kasvutingimustesse ja säilitab endale omase suhtumise päeva pikkusesse, võib see temale saatuslikuks saada ja pōhjustada isegi tema hävingu.

Kuna eri ristikusortide fotosünteetiline tegevus on enam-vähem sarnane, tuleb nende pōhilisi sordierinevusi otsida metabolismiprotsessides ja plastiliste ainete kasutamise viisides.

Eesti NSV Teaduste Akadeemia

Eksperimentaalbioloogia Instituut

Saabus toimetusse

10. XII 1957

\section{AKKUMULATION DER TROCKENSUBSTANZ UND VERWENDUNG DER PLASTISCHEN STOFFE BEI DEN VERSCHIEDENEN ROTKLEESORTEN IM SAATJAHR}

\section{W. Duschetschkin}

\section{Zusammenfassung}

Auf eine Einheit der Anbaufläche gerechnet, produzieren verschiedene Rotkleesorten bei geschlossenem Bestande die Trockensubstanz mit fast gleicher Intensität.

Die sogenannte reine Produktivität der Photosynthese (täglicher Zuwachs der Trockensubstanz pro Blattflächeneinheit) war bei verschiedenen Rotkleesorten von annähernd gleichem Wert.

Bei 24-stündiger Tageslänge werden die löslichen Photosyntheseprodukte verschiedener Rotkleesorten in gleicher Weise verwendet - hauptsächlich zum Aufbau oberirdischer Organe. Beim Verkürzen der Tageslänge werden die löslichen Syntheseprodukte je nach der Kleesorte unterschiedlich realisiert; bei winterfesteren Sorten werden sie zum Aufbau verdickter Wurzeln und verkürzter Ausläufer verwendet, wobei das Höhenwachstum der Staude stark unterdrückt wird.

Vom Mengenverhältnis der für das Wachstum verschiedener Organe benutzten Assimilate hängt je nach der Tageslänge sowohl die Produktionsfähigkeit, als auch die Winterfestigkeit der Kleesorten ab.

Das verschiedene Verhalten der Kleesorten erklärt sich nicht durch ungleiche photosynthetische Tätigkeit, sondern durch diejenigen Eigenschaften, von welchen - den Wachstumsbedingungen gemäss - der Charakter des Metabolismus und die Verwendungsart der löslichen Syntheseprodukte abhängen. 